\title{
Medical pot users sue for right to grow
}

$\mathrm{S}$ hawn Davey's unsteady gait is the result of a motor-vehicle crash 15 years ago that left him with numbness on one side of his body, constant pain and a brain injury that has affected his memory.

After spending thousands on prescription drugs, Davey says marijuana was the only thing that helped. "I was supposed to be in 24/7 care for the rest of my life," says Davey. "Now I live on my own. It's all due to marijuana."

Davey is among a group of British Columbia residents challenging the federal government's 2013 reforms to the rules covering cultivation of medicinal marijuana on constitutional grounds. They're demanding that the government reinstate their right to grow their own pot instead of being forced to buy from largescale commercial suppliers. A three-week Federal Court hearing began Feb. 23 in Vancouver before Judge Michael Phelan.

The plaintiff's lawyer, John Conroy, is arguing the regulations restrict users' choice, increase cost and limit how much they can possess. They're forced to choose between their health and their freedom if they keep growing their own.

Justice Department lawyer Jan Brongers contends the new rules were needed to bring order to the largely unmonitored medicinal marijuana sector, seen by some as rife with illicit sales and safety risks.

Davey told the court the marijuana he and a friend grow in a secure outbuilding is superior to and cheaper than the product he used to get from a designated grower. Commercially grown cannabis would cost nearly $\$ 4000$ a month, he said.

More than that, though, his bad experiences with poor-quality pot make him distrust outside suppliers.

Launched a year ago, the challenge has thrown a wrench into the Conservative government's Marihuana for Medical Purposes Regulations (MMPR), which shift growth and sale of medical marijuana to licensed fully commercial operations from a mix of for-profit and grow-your-own cultivation. The new rules also limit the amount a user can legally possess to 150 grams, down from the previous limit of a 30-day supply.

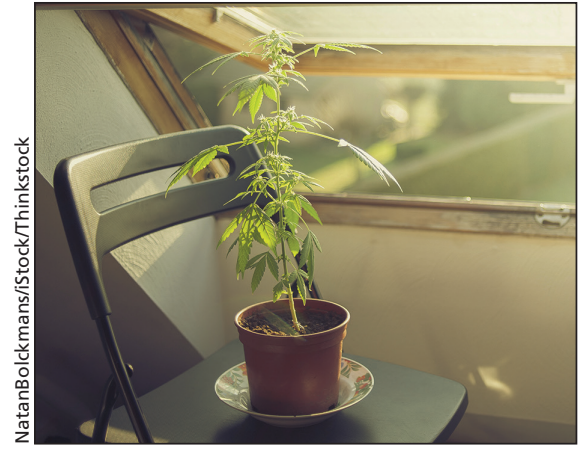

Some BC residents are fighting for the right to grow their own medical marijuana.

The deadline for the change was Apr. 1,2014 , but in late March a federal judge granted a temporary injunction allowing Canadians with medical marijuana permits to keep their current arrangements pending the court's decision in late summer or fall.

Speaking before Judge Phelan, Conroy said the MMPR violates Section 7 of the Charter of Rights and Freedoms protecting life, liberty and security of the person. He said the onus is on the government to show the new rules constitute a reasonable limitation of those rights under Section 1 of the charter. "The government bears the burden in justifying any intrusions on a person's liberty and security of the person," he said.

Brongers said the government will show changes were necessary to address "exponential growth" in demand. The original rules were designed for a relatively small number of users, he said.

The number of licensed growers had mushroomed from fewer than 100 in 2001 to some 37000 in January 2014, according to the government's statement of defence. The difficulty in monitoring so many grow-ops caused concern among police, fire, health and safety authorities.

Brongers said there is no constitutional right to access unlimited amounts of pot from any source.

The government will call witnesses to show Canada's approach is in line with other countries that permit medical marijuana use, including the United States, Israel and the Netherlands. Steve Mertl, Vancouver, BC

CMAJ 2015. DOI:10.1503/cmaj.109-5008 